\title{
Experimental methods to evaluate herbicides behavior in soil
}

\author{
Métodos experimentais para avaliação do comportamento dos \\ herbicidas no solo
}
Fabio Schreiber ${ }^{1 *}$, Ananda Scherner ${ }^{2}$, Andre Andres ${ }^{1}$, Germani Concenço ${ }^{1}$, William Christofari Ceolin², Matheus Bastos Martins ${ }^{2}$

\begin{abstract}
Pesticides are an essential tool for agriculture, however, studies have been shown that only $45 \%$ of the sprayed products reach the target-crop, whereas $30 \%$ is drifted, $10 \%$ is lost due to transport processes (leaching, volatilization and runoff), and 15\% reaches the soil. Moreover, only $1 \%$ of the applied product reaches the target, in other words, the pathogens, weeds and insects. Even though, risk assessments for environmental contamination due to off-target movement of a pesticide are mandatory and performed prior to its registration, these products are often detected contaminating non-target sites, and freshwater ecosystems are the main impaired. Various biological, physical and chemical processes determine the environment fate and the efficacy of these compounds. Thus, there are several experimental techniques used to evaluate the behavior of herbicides in soil. This review aims to summarize the most commonly used methods to describe and evaluate each process to which a herbicide is subjected in soil and, their advantages and disadvantages. In general, when studying the fate of pesticides in the environment, laboratory experiments provide more precise information because it is possible to control the environmental conditions and isolate the factors that interest the researcher. However, it is important to mention that there is not a more efficient method but there are methods that can provide a better result in a given situation. Thus, the method choice depends in the study aim and the available infrastructure.
\end{abstract}

Keywords: adsorption, biodegradation, leaching, runoff, volatilization

Resumo - O uso de agrotóxicos na agricultura é praticamente indispensável, contudo, estudos estimam que somente $45 \%$ do produto aplicado atinge a cultura, sendo que aproximadamente $30 \%$ sofrem deriva, $10 \%$ são perdidos por algum processo de transporte (lixiviação, volatilização e escoamento) e $15 \%$ atingem o solo. Além disso, do total aplicado, apenas 1\% atinge o alvo, ou seja, patógenos, plantas daninhas e insetos. Embora avaliações de riscos de contaminação ambiental de agrotóxicos sejam obrigatórios para o registro e comercialização, frequentemente estudos relatam a presença destes em locais não alvos, sendo os corpos de água os principais prejudicados. Vários processos biológicos, físicos e químicos determinam o destino ambiental e a eficiência desses. Assim, diversos métodos experimentais podem ser utilizados para avaliar o comportamento de agrotóxicos no ambiente. Essa revisão objetiva resumir os métodos mais comumente utilizados para descrever

\footnotetext{
Received: October 09, 2017. Accepted: April 29, 2017.

${ }^{1}$ Setor de herbologia, Núcleo de Bioeficiência, Embrapa Clima Temperado, Empresa Brasileira de Pesquisa Agropecuária - EMBRAPA, Endereço Rodovia BR 392, km 78, CP 403, CEP 96010-971, Pelotas, RS, Brazil. E-mail: schreiberbr@gmail.com.br; andre.andres@embrapa.br; germani.concenco@embrapa.br

2 Programa de Pós-graduação em Herbologia, Departamento de Fitossanidade, Universidade Federal de Pelotas - UFPel, Pelotas, RS, Brazil. E-mail: anandascherner@hotmail.com; willian.ceolin@hotmail.com; matheusbastosmartins@gmail.com
} 
e avaliar os processos nos quais o herbicida esta sujeito quando presente no solo, bem como, as vantagens e desvantagens de cada um desses. No geral, em se tratando de destino de agrotóxicos no ambiente, os experimentos em laboratórios fornecem informações mais precisas, pois é possível controlar melhor as condições ambientais e isolar fatores de interesse. Mas é importante salientar que não existe um método mais eficiente, o que existe são métodos que podem fornecer um melhor resultado em determinada situação. Por tanto, a escolha do método vai depender do objetivo do estudo e da estrutura disponível.

Palavras-chave: adsorção, biodegradação, escoamento superficial, lixiviação, volatilização

\section{Introduction}

In conventional agriculture the use of herbicides is an indispensable tool for obtaining high yields. However, during spraying and after deposition within the target site, numerous biological, physical and chemical processes determine the fate of the herbicide and its efficacy (Gavrilescu, 2005). Some of the sprayed herbicide is taken up by plants, while some reaches the soil where it is subjected to transport, transformation and retention processes (Figure 1) and, consequently, may not contribute to weed control. Therefore, when the portion of the herbicide that is not available for weed control is higher than the available share, its efficacy and the duration of the effect in soil is greatly reduced (Melo et al., 2016). Moreover, off-target movement of herbicides is both an ecological and human health concern (Westra et al., 2014).

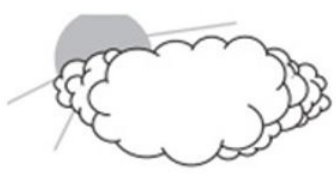

Photodegradation

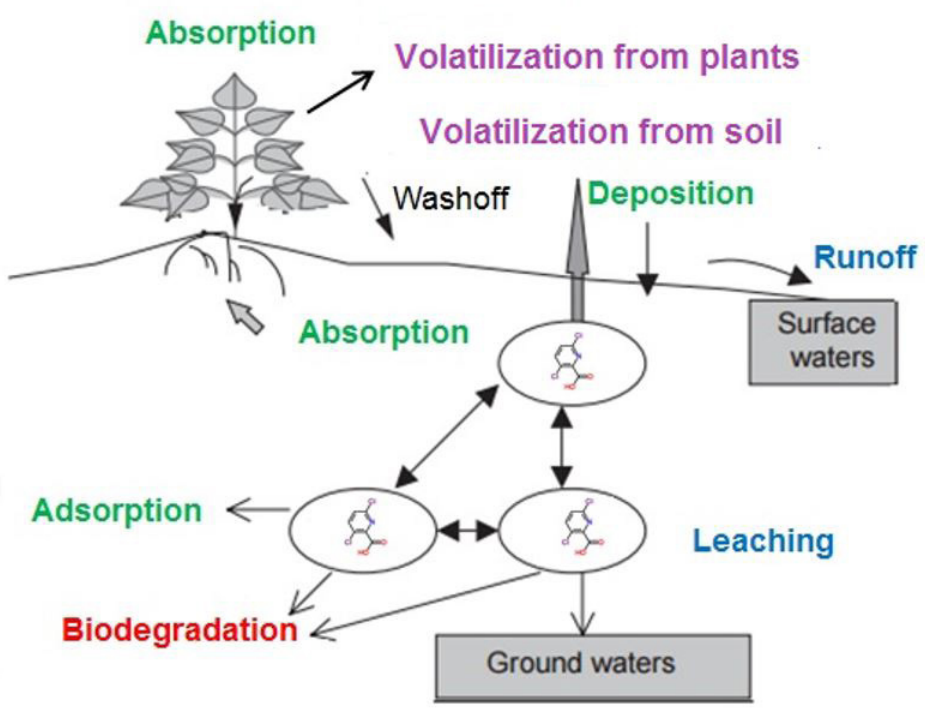

Figure 1. Major processes involved on the behavior of herbicides in the environment after spraying on soil or plant surfaces. Adapted from Bedos et al., (2002a). 
It is estimated that less than $1 \%$ of the total pesticide sprayed reaches the target, such as pests and weeds (Pimentel, 1983; Zhang et al., 2004). Other authors believe that about $45 \%$ of the pesticides reaches the target crop, whereas $30 \%$ is lost by drift, $10 \%$ is transported (volatilization, leaching and runoff) and 15\% reaches the soil (Gavrilescu, 2005). Nevertheless, the water bodies are the main fate of pesticides once sprayed in the cropping field and, thus, decades of monitoring studies have been documenting the occurrence of pesticide residues at trace concentrations in watercourses around the world (Ronco et al., 2016; Sakai et al., 2016), mostly making it unfit for consumption.

Herbicide transportation in the soil is mainly achieved via volatilization, leaching and surface runoff processes (Logan, 1999), which can move the compound a long way from its point of introduction (Gavrilescu, 2005). Volatilization is a physico-chemical process in which a compound in its solid phase is transferred from the soil or plant surface to the gaseous phase (Bedos et al., 2002a). This process can occur as soon the herbicide is sprayed and its re-deposition on non-target organisms is a source of environmental contamination (Schreiber et al., 2013; Schreiber et al., 2015). Leaching is the vertical and/or horizontal movement of the herbicide into the soil profile, which can lead to the contamination of surface and groundwater (Cohen et al., 1995; Whitford et al., 1995). Surface runoff occurs when the herbicide is carried off the soil surface with water and/or soil sediments. This process contributes to the contamination of surface water and occurs mainly in sloping areas (Cohen et al., 1995).

Transformation processes are the main factors responsible for the decline in herbicide concentrations in the environment after application. Biodegradation is the main source of herbicide degradation in soils and occurs when microorganisms use the compound as a source of carbon and energy (Waldman and Shevah, 1993). Furthermore, the availability of herbicide in the soil solution can be reduced due to its adsorption to soil particles. This process is a result of the interaction between the chemical compound and soil particles, and depends on characteristics of both (Kan et al., 1994).

Although transport, transformation and retention processes are here described isolated, it is important to highlight that they interact with each other. The intensity at which the herbicide is subjected to each of these processes is mainly dependent on the nature of the compound and its physico-chemical characteristics (Foght et al., 2001). Herbicide features such as water solubility, vapor pressure, adsorption coefficient and acid-base strength ( $\mathrm{pKa}$ and $\mathrm{pKb}$ ) have to be taken into account to predict herbicide behavior (Gavrilescu, 2005). Soil characteristics such as texture, particle size distribution, permeability, $\mathrm{pH}$, organic matter and slope influence the rate at which the processes occur in the soil (Dao and Lavy, 1978; Fushiwaki and Urano, 2001). Moreover, climatic conditions before, during and after spraying interact with all the other factors to determine dissipation processes and herbicide fate (Gavrilescu, 2005).

Due to the magnitude of parameters that can interfere on the herbicide behavior in soils, studies are generally carried out under different field and laboratory scenarios, with very specific and rigorous conditions. This review aims to present the most common scientific methods that have been used to describe processes regulating herbicide behavior in soil. Scientific method in this study is defined as an experimentation process that is used to explore observations and answer questions. The methods here described are grouped according to the nature of the process they characterize: transport (I), transformation (II) and retention (III) of herbicides in soil.

\section{Characteristics of scientific methods}

Field and laboratory studies can be conducted to characterize the rates and relative importance of the different transport, transformation and retention processes that regulate the dissipation of 
a herbicide in soil. Field experiments provide more realistic environmental conditions. However, in laboratory the environmental conditions are strictly controlled, whereas under field conditions, where the soil water content, temperature, and air flow-rate undergo constant change, quite different rates of degradation and mobility may occur. Whenever feasible, these two experimental approaches should be carried out together to determine potential transportation routes.

The majority of the experimental techniques presented in this review can be further assessed by bioassays and analytical techniques. Bioassays are often considered a more conventional and time consuming approach than analytical analysis. However, bioassay technique is quite sensitive to detect not only the presence of the parent compound in the soil but also phytotoxic metabolites (Rupak et al., 2009). On the other hand, analytical analysis, such as chromatography, with detection systems that range from simple UV (ultra violet) absorbance detection to sophisticated mass spectrometric analysis, can accurately quantify residual concentrations of the herbicide, even in low concentration. However, they are expensive requiring specialized equipment and laboratory infrastructure (Strachan et al., 2011). Moreover, when studying the behavior of certain compounds

in the soil both non-radiolabeled and radiolabeled herbicides can be used. More sensitive methods can be used to detected and quantify compounds concentration by using radiolabelled herbicides, however, in field conditions non-radiolabeled substances are preferred. Moreover, field studies should not be conducted in critical habitats or areas containing endangered species (EPA, 2008).

Each method described in this study can be classified in several categories, which are fundamental attributes that should be taken into account by researchers prior choosing the experimental approach. Figure 2 in this study ranks (from zero to 10) the use of different experimental environment (field, laboratory and prediction methods) and assessments methods (analytical techniques, bioassays and use o radiolabelled herbicides) cited above in this review according to their fundamental attributes. Nevertheless, one should note that the assessment and experimental methods were ranked according to authors' knowledge and opinion.

The meaning used by the authors of each item in this rank is presented below:

- Costs: includes the general costs of the materials to be used exclusively in the experiment.

- Time: if the method is fast or time consuming.
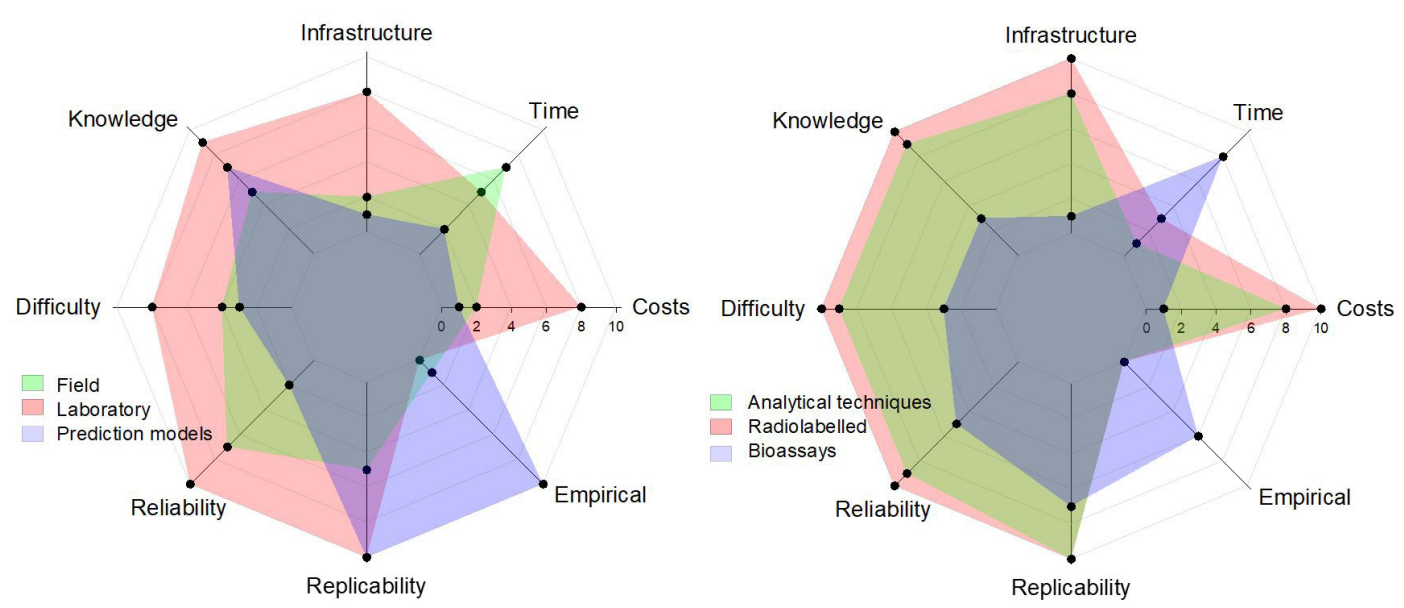

Figure 2. Radar plots ranking (from zero to 10) the fundamental attributes of experimental type (left) and assessments methods (right) used to evaluate the behavior of herbicides in soil. 
- Infrastructure: need of facilities that should be available to conduct the method.

- Knowledge: level of experienced required by the researcher when conducting the method.

- Difficulty: amount of effort that should be given to conduct the method.

- Reliability: the findings derived from actual data would generate conclusion and interpretations that are consistent with the facts as it is, rather than on beliefs, wishes or desires.

- Replicability: when another person duplicates the experiment will get the same results.

- Empirical: the method relies on direct observation from other studies.

These fundamental attributes are also used later is this study to evaluated (rank) the experimental techniques for each process that regulate herbicide behavior in soil (transport, transformation and retention).

\section{Transport}

\section{Plant uptake}

Plants can intercept the sprayed herbicide in their aboveground portions and uptake it from the soil via roots. As the present review aims to explore the methods used to evaluate the behavior of herbicide in soil only root uptake will be considered. The most reliable method to study plant uptake is obtained by evaluating both concentrations of the herbicide on the crop and on the soil underneath the crop (Beinum and Beukle, 2010). Though, there is no accepted standard method for conducting plant uptake studies.

Plant uptake via the roots is passive, with chemicals moving into the plant along with the water used for transpiration. This implies that the longer the exposure and the greater the amount of water transpired the more herbicide that will be taken up by the plant. In these studies the plants are exposed to a constant root-zone concentration of the herbicide in a hydroponic environment and the compound concentration in the above ground plant tissue is measured on the xylem (Dettenmaier and Doucette, 2007).

In soil exposure systems, whether performed in the laboratory or measured under field conditions, it is generally easier to measure the concentration of chemical in the soil surrounding the plant than the chemical concentration in the xylem (Dettenmaier and Doucette, 2007). Thus, field studies should reflect normal conditions and practices and actual use of the tested herbicide including cropped and non-cropped plots and, an untreated control plot (Corbin et al., 2006). The sampling scheme should be designed to track the decline in herbicide residues from soil with time, and should include a time zero residue level.

\section{Leaching}

The potential threat of a herbicide to contaminate groundwater or its leaching potential is commonly assessed by using zero-tension lysimeters that can be installed in laboratory and/or field conditions. Lysimeters are soil monoliths, usually of cylindrical shape, enclosed in a casing and open at the top. These structures have variable lengths, diameters and a made from several inert materials such as PVC and metallic-materials. Sensors can be installed at different depths into the soil monolith to measure soil moisture, temperature and electrical conductivity (Bergstrom, 1990).

Lysimeters are usually filled with undisturbed soil or installed under field conditions where the herbicide is applied on the bare soil surface. It is extremely important to use intact soil cores in these studies to maintain the soil structure. Moreover, outdoor studies which are subjected to natural rainfall, temperature variations and wind tend to provide results more closely associated to the reality. However, one important disadvantage of this method is that the natural water flow is affected due to reduced water mobility inside the lysimeter structure, which creates a local saturation that affects solute transport before water drainage takes place (Kasteel et al., 2007). 
Herbicide concentrations in lysimeter studies can be analyzed in the drainage water or from soil samples taken at different periods after its application, and from distinct soil layers. Thereafter, water and soil samples are normally subjected to bioassays and/or analytical analysis to assess and quantify herbicide concentrations (Shukla et al., 2006).

The use of prediction models and index methods are also very common tools to describe leaching risk of a herbicide, and has been widely used to build up vulnerability maps based on local soil traits (Tiktak et al., 2004). Prediction models as such PELMO (Jene, 1999), PRZM (Carsel et al., 2003) and PEARL (Tiktak et al., 2000) provide relevant information on transport processes. However, they require specific computing skills and can be time consuming, demanding a substantial amount of information to be gathered, which are not always available (Kasteel et al., 2007). On the other hand, index methods such as the GUS and GOSS (Gustafson, 1990; Goss, 1992) are easy to use requiring few input parameters; however, they do not consider important information regarding soil features (Lindahl et al., 2008).

\section{Volatilization}

The volatility potential of a herbicide, which represents the risk to contaminate the atmosphere and consequently non-target organisms, can be measured and estimated with several methods. Volatilization can be assessed by using micrometeorological system (Majewski, 1999), field and semi-field conditions (Van den Berg et al., 1999), closed-chambers (Schreiber et al., 2013; Schreiber et al., 2015) and wind tunnels (Bedos et al., 2002b).

Wind-tunnel technique is widely used to measure the volatilization flux of herbicides because it is very practical and can be installed indoor and in field conditions (Schreiber et al., 2016). Indoor systems determine the movement of molecules through the air due to the presence of an uniform air flow, where environmental conditions, such as temperature, air humidity and speed, can be controlled. This method is very reliable and can be easily executed and reproduced. However, indoor wind-tunnels are closed systems with specific microclimates that can under or super estimate the volatilization risk of certain herbicide when compared to natural conditions (Shigaky and Dell, 2015). Moreover, construction and maintenance costs of indoor wind-tunnels are very expensive (Moreira Junior and Antuniassi, 2010). To assess the volatilization rate the air is collected with special samplers in the entrance and exit of the tunnel (Leistra et al., 2008) or with indicator organisms over the tunnel.

Wind-tunnels installed under field conditions permit exchange with the atmosphere, and though environmental conditions are not controlled, they are still monitored. These tunnels are often cheaper in comparison to indoor tunnels and provide representative data of natural conditions (Schreiber et al., 2016). Wind direction and speed are not constant in these systems, affecting the distribution of herbicides into the atmosphere (Mahugija et al., 2015) and, therefore, volatilization can be either super and under estimated. However, this system is very useful for comparison with estimates under more controlled conditions (Schreiber et al., 2016).

Another more conventional low-cost method to assess air contamination is in closed-chambers (Nunes and Vidal, 2009). Bioindicator plants can be used to evaluate the volatility risk of a herbicide in closed-chambers and/or field conditions (Schreiber et al., 2013; Schreiber et al., 2015; Schreiber et al., 2016). Herbicides concentrations in air are evaluated by the symptoms caused on the bioindicator plants, which are used instead of atmospheric measurements and analytical analysis (Lam and Gray, 2003). However, the method requires previous test for possible bioindicator organisms for each herbicide, which can be time consuming. Moreover, to observe the effects on the organism, direct contact between plants and contaminated air with the herbicide has to be ensured. On the other hand, active samplers allow researchers to quantify the volatilization 
over the time, given more precise indications on the volatilizations rate of certain herbicide.

The most common sampling techniques for pesticides in air can be grouped into two categories: active and passive samplers Passive air samplers are based on the principle of diffusion (Górecki and Namiesnik, 2002). These samplers do not need power supply and tend to be cheaper and lighter that active air samplers. In active air samplers the air is pumped through a glass-fiber filter and a resin plug where the molecules will adsorb (Scheyer et al., 2005), allowing to study spatial and temporal variations of the pesticide concentrations in the air (Schummer et al., 2010). However, these samplers are quite heavy, expensive and can be only used where electricity is available. The efficiency of the sampling also will depend the compound in study and the adsorbent used such as semi-permeable membrane (Bartkow et al., 2004), PUF (polyurethane foam)-based (Schummer et al., 2012), Tenax TA (Briand et al., 2002) and stainless steel meshed cylinder filled with XAD-2 (Wania et al., 2003). Thereafter, the samples are analyzed with analytical techniques using chromatography, mainly GC-MS (gas chromatography - mass spectrometry) and LC-MS (liquid chromatography - mass spectrometry) based methods.

Simulation of herbicide emission from soil to the atmosphere is another key component for risk assessment of volatilization. There are some dynamic models (PEARL, MM5 and PEM models) devoted to prediction of pesticide volatilization, but they generally cannot accurately simulate high emission rates (Li, 2012). Moreover, most current models do not address processes occurring in the soil, atmosphere, and effects of agricultural practices when assessing herbicide volatility risk.

\section{Surface runoff}

These studies are normally performed under typical field conditions relying on natural rainfall and, therefore, undoubtedly provide data representative of natural conditions. They are also cheaper and simpler than the ones in artificial conditions. However, the unpredictably of rain can make this frustrating and the study cannot be repeated or extrapolated to other conditions because the results are originated from a complex and uncontrolled system (IUPAC, 1995). Thus, the alternative is to use simulated rainfall (Wauchope and Burgoa, 1995), where the experimental design is often associated with the objectives and the scale of the study.

Experiments using simulated rainfall are of smaller scale, often conducted in soil boxes, in which all environmental variables are controlled. This method can be easily reproduced and manipulated and is good for comparative evaluations of certain environmental condition on runoff, as the amount and type of rainfall. However, the results from these studies are realistic only for very homogeneous situations such as herbicide behavior in flat soils because only a single point on soil surface is represented (Wauchope and Burgoa, 1995). Moreover the majority of the simulators is usually restrict to small plots which not reproduce real conditions of surface flow, because large plots are expensive and have a high labor requirement to operate.

In these studies water samples are collected for each rainfall event after application of the herbicide until its concentration decreases below the level of detection. Thus, depending on the site and its topography, small plots can be instrumented to allow automated collection of runoff water from the entire field by installing collection devices at the down-slope edge. Larger plots require installation of collection devices at several predetermined locations.

Simulation models are also used to assess the pollution risk associated with herbicide runoff, providing reliable information. Mechanistic models such as SWAT, PRZM, and VFSMOD are used to approximate pesticide losses in runoff events (Gali et al., 2016). However, because rainfall is uncontrolled the risk-of-runoff has to be assessed with representative data sets, which integrate information from a combination tests in field conditions under natural and simulated rainfall. Therefore, these models can be very time-consuming due to the amount of data required to produce reliable information. 


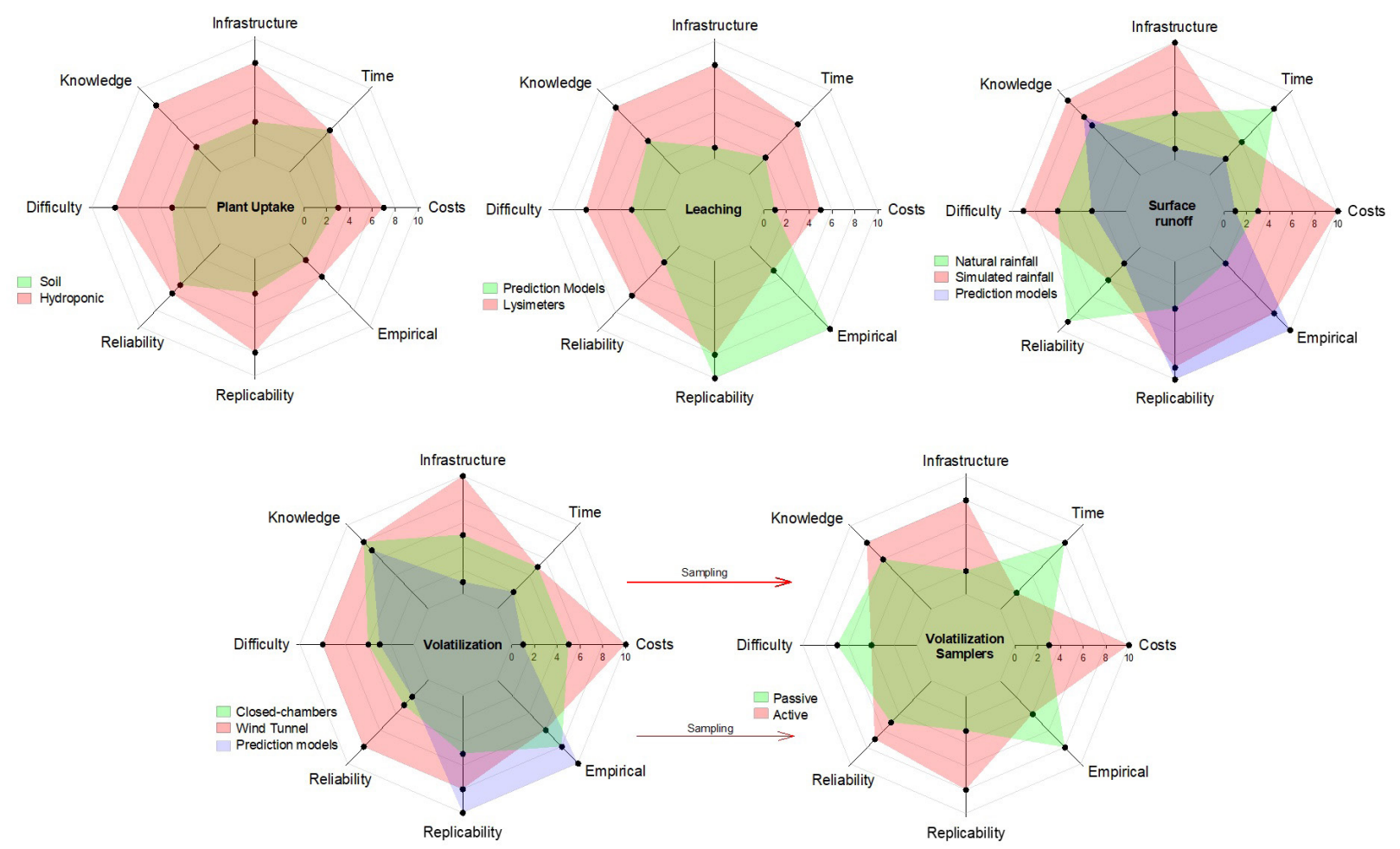

Figure 3. Radar plots ranking (from zero to 10) the fundamental attributes of scientific methods used to evaluate transport of herbicides in soil.

This section presented the most commonly experimental methods used to evaluate transport processes, which had their fundamental attributes (as described in the previous section) ranked in Figure 3.

\section{Transformation}

Degradation is a key process determining the fate of pesticides in the environment (Linn et al., 1993). Degradation processes can be biotic (occurring via soil microorganisms) or abiotic and are influenced by several factors, including $\mathrm{pH}$, organic matter content, moisture content, texture and microbial activity (Lourencetti et al., 2012.). Several transformation products can be formed, and/or complete degradation (mineralization) can take place (Fomsgaard and Kristensen, 1999).

Microorganisms are present in soil as an uncountable number of species and biodegradation is one of the main processes reducing herbicide concentration in soil (Waldman and Shevah,
1993). Thus, on the following are presented the most commonly experimental methods used to evaluate herbicide biodegradation and metabolite formation. There are several methods to estimate the microbial herbicide degradability, however all approaches have to consider the following guidelines (EPA, 2008):

- Soil sampling has to be carefully planned to provide representative results;

- Soil sampling must be performed in fields that not have been sprayed with herbicides in previous years;

- Incubation studies may take more than a year if the herbicide is transformed slowly;

- The initial concentration of the herbicide should be as close as possible from the ones expected in field conditions. 
A conventional approach to assess degradability potential is to perform tests simulating biodegradation in soil under anaerobic and aerobic conditions, where the herbicide is incubated under static soil moisture and temperature conditions in the dark, in either flow-through or biometer test systems, after application of the active substance (OECD, 2005). The use of radiolabeled material is preferred. During incubation soil samples are taken at different time points and analyzed for active substance, metabolites, volatile components and bound residues. A minimum of six sampling times (including zero time) is considered necessary toestimate kinetic endpoints over an experimental period not normally exceeding 100 days. The time taken for degradation of $50 \%$ and $90 \%$ of the active substance and major metabolites is derived from the formation and decline curves (OECD, 2005).

Soil samples can also be collected at different time-points from field experiments using soil columns or micro-lysimeters where the herbicide was sprayed (OECD, 2005). The potential advantage of these systems is that the conditions of incubations are much more similar to the actual conditions present in an agricultural field after application of the active substance. However more variation should be expected from these samples once environmental conditions are not controlled. Moreover, initial concentration of the herbicides at the first sampling date may not coincide with the sprayed dose due to the occurrence of other dissipation processes, though these estimates are more close to the reality.

The herbicide activity in laboratory or field samples can be analyzed via analytical methods and bioassays (OECD, 2005; EPA, 2008). Analytical analysis, especially for the experiments using radiolabeled herbicides, would provide information on the transformation kinects of this compound as well once the degradation pathway is detected, which may give evidence of degradation in the field (Dettmer et al., 2007; Etzerodt et al., 2008; Boesten et al., 2005). However, bioassays can add information on the susceptibility of plants to very low concentrations of the herbicide in soil, which from an agronomic point of view is of great interest (Rupak et al., 2009), mainly to non-target plants.

Another method is to study the potential of a microbe community for herbicide biodegradation through the isolation and characterization of microbial strains (EPA, 2008; OECD, 2005). This is a complementary and more quantitative technique, where genes are quantified via quantitative polymerase chain reaction (QPCR), high-throughput gene sequencing, or use of functional gene microarrays, methodologies that have become easily accessible and have a promising future (Fenner et al., 2013). Nevertheless, the technique requires that involved genes are known and can be clearly attributed to a given transformation reaction.

\section{Retention}

Adsorption/desorption behavior on a herbicide is studied to estimate its retention in soil and probably is the most important mode of interaction between soil and herbicides. These studies aim to obtain sorption-desorption coefficients $(\mathrm{Kd})$, that can be used to predict partitioning under a variety of environmental conditions (EPA, 2008). The Kd represents the magnitude of sorption and, therefore, the greater the $\mathrm{Kd}$ the greater the sorption (Azcarate et al., 2015). Thus, this information can be used in the prediction or estimation of the herbicide availability for transport, transformation and uptake by plants. There are some guidelines that have to be followed in relation to soil and sampling procedures (EPA, 2008):

- The soils should be characterized by parameters considered to be largely responsible for the adsorptive capacity: organic carbon, clay content, $\mathrm{pH}$, textural composition and textural class;

- Soil samples should be collected at the A horizon up to a maximum depth of $20 \mathrm{~cm}$; 

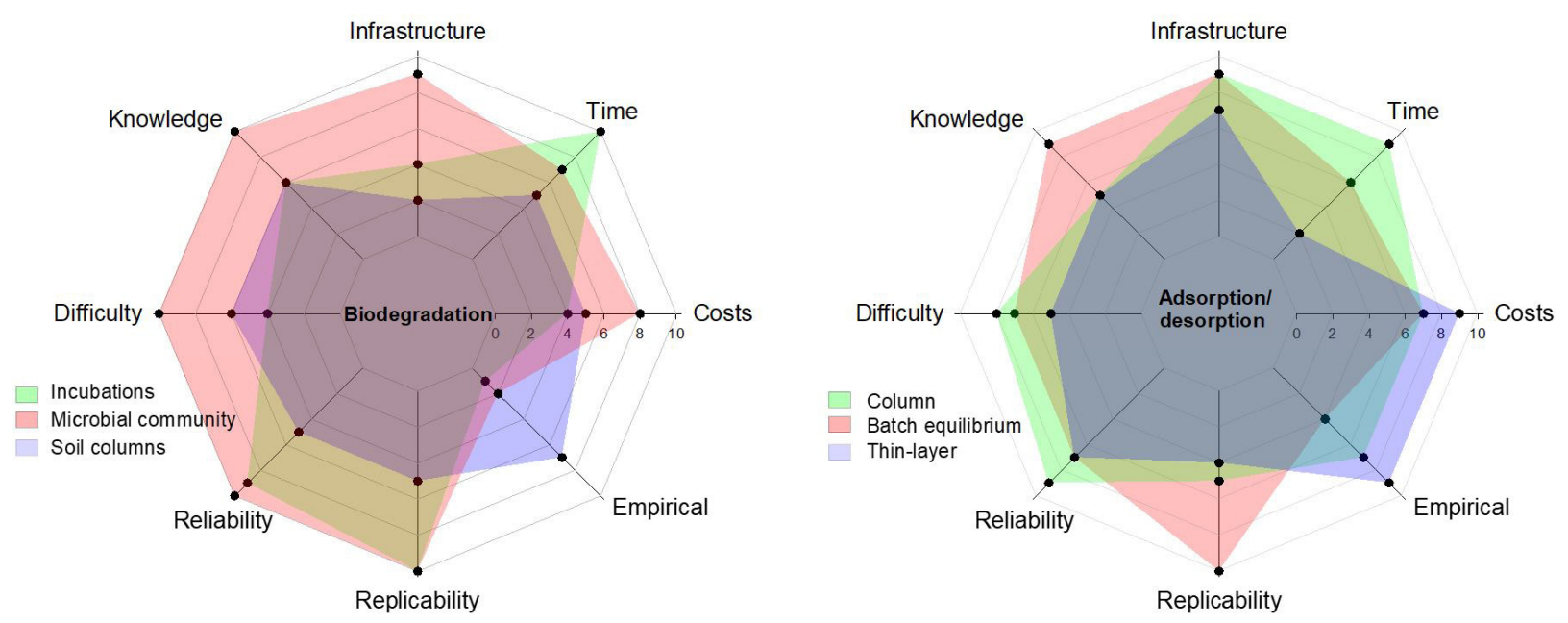

Figure 4. Radar plots ranking (from zero to 10) the fundamental attributes of scientific methods used to evaluate transformation (left) and retention (right) of herbicides in soil.

- The use of soils freshly taken from the field is preferred.

There are three main techniques used to direct measure Kd, which are batch equilibrium, soil column measurements and soil thin-layer chromatography (Wauchope et al., 2002). The standard method to determine adsorption/desorption is by batch equilibrium (Singh et al., 1990; OECD, 2005), where radio-labeled or non-radio labeled herbicide is added to the soil/water mixture and this material is equilibrated. After equilibration, suspensions are centrifuged and the supernatant is removed and the herbicide is determined by analytical analysis or in the case of radio-labeled herbicides by liquid scintillation counter. The amount of herbicide adsorbed by the soil is calculated from the difference between the initial and equilibrium herbicide concentrations in solution (OECD, 2005). Thereafter, the equilibrium sorption is commonly described by an empirical relationship using adsorption isotherms. Freundlich and Langmuir are two well-known adsorption isotherm. Freundlich equation has great advantages due to its flexibility, allowing comparison of the extent of herbicide adsorption in different soils, whereas the main application of Langmuir equation is the ability to estimate the herbicide maximum adsorption
(Hussain et al., 2003). However, some authors pointed out possible disadvantages for Freundlich equation because it is an empirical approach without theoretical basis. Moreover, it fails when the concentration of the adsorbate is very high (Nichols, 1992).

Column measurements are more complicated than batch equilibrium studies, however, they provide more information about the herbicide mobility and is closer to field conditions (Wauchope et al., 2002). On the other hand, thin-layer chromatography is a simple and quick to measure herbicide mobility between soils (Helling and Turner, 1968), though the results are less precise than column measurements and, therefore, the method is not well accepted nowadays (Wauchope et al., 2002).

The fundamental attributes of scientific methods used to evaluate transformations and retentions of herbicides in soil were ranked (from zero to 10) and are shown in Figure 4.

\section{Conclusions}

It is difficult to assess the overall fate of pesticides in soil without expending some time deciding on the methods to be used. There are many factors that have potential influence on the behavior of pesticides in soil. Sometimes it 
is necessary to associate techniques to reach the aim. The information provided in this review summarizes the current experimental techniques that have been mainly used to evaluate the plant uptake, leaching, volatilization and runoff potential of herbicides in soil. Furthermore, methods to evaluate the degradability potential via biodegradation and the retention in soil are also cited. The benefits and drawbacks of each technique were emphasized, which are mainly associated with the magnitude of parameters that can interfere on herbicide behavior in soil. Thus, this review highlights the need to integrate experimental approaches to yield better estimates that are closely linked with the behavior of the herbicides in natural conditions.

\section{References}

Azcarate, M.P.; Montoya, J.C.; Koskinen, W.C. Sorption, Desorption and Leaching Potential of Sulfonylurea Herbicides in Argentinean Soils. Journal of Environmental Science and Health. Part. B, Pesticides, Food Contaminants, and Agricultural Wastes, v.50, n.4, p.229-237, 2015.

Bartkow, M.E.; Huckins, J.N.; Müller, J.F. Fieldbased evaluation of semipermeable membrane devices (SPMDs) as passive air samplers of polyaromatic hydrocarbons (PAHs). Atmospheric Environment, v.38, n.1, p.5983-5990, 2004.

Bedos, C.; Cellier, P.; Calvet, R.; Barriuso, E.; Gabrielle, B. Mass transfer of pesticides into the atmosphere by volatilization from soils and plants: overview. Agronomie, v.22, n.1, p.21-33, $2002 \mathrm{a}$.

Bedos, C.; France, M.R.; Flura, D.; Masson, S.; Barriuso, P.C. Rate of pesticide volatilization from soil: an experimental approach with a wind tunnel system applied to trifluralin. Atmospheric Environment, v.36, n.3940, p.5917-5925, 2002b.

Beinum, W.; Beukle, S. Collection and evaluation of relevant information on crop interception for the revision of the Guidance Document on Persistence in Soil. EFSA Supporting Puplications, v.7, n. 10, p.1-41, 2010.

Bergstrom, L. Leaching of chlorsulfuron and metsulfuron methyl in three Swedish soils measured in field lysimeters. Journal of Environmental Quality, v.19, n.4, p.701-706, 1990.

Boesten, J.J.T.I.; Aden, K.; Beigel, C.; Beulke, S.; Dust, M.; Dyson, J.S. et al. Guidance document on estimating persistence and degradation kinetics from environmental fate studies on pesticides in EU Registration. FOCUS, 2005. Available from: <http://eusoils.jrc.ec.europa. eu/public_path/projects_data/focus/dk/docs/ finalreportFOCDegKinetics.pdf $>$. Accessed: 02 mar. 2017.

Briand, O.; Millet, M.; Bertrand, F.; Clément, M.; Seux, R. Assessing the transfer of pesticides to the atmosphere during and after application. Development of a multiresidue method using adsorption on Tenax and thermal desorption-GC/ MS.Chem. Analitycal Bioanalitycal Chemistry, v.374, n.5, p.848-857, 2002.

Carsel, R.F.; Imhoff, J.C.; Hummel, P.R.; Cheplick, J.M.; Donigian, A.S.J. PRZM-3: a model for predicting pesticide and nitrogen fate in the crop root and unsaturated soil zones. EPA, 2003. Available from: <archive.epa.gov/scipoly/ sap/meetings/web/pdf/przm.pdf $>$. Accessed: 15 mar. 2017.

Cohen, S.Z.; Wauchope, R.D.; Klein, A.W.; Eadsforth, C.V.; Graney, R. Offsite transport of pesticides in water: mathematical models of pesticides leaching and runoff. Pure and Applied Chemistry, v.67, n.12, p.2109-2148, 1995.

Corbin, M.; Eckel, W.; Ruhman, M.; Spatz, D.; Thurman, N.; Gangaraju, R.; et al. NAFTA guidance document for conducting terrestrial field 13 dissipation studies. 2006. Available from: $<$ http://www.epa.gov/oppefed1/ecorisk_ders/ terrestrial_field_dissipation.htm>. Accessed: 14 mar. 2017. 
Dao, T.H.; Lavy, T.L. Atrazine adsorption of soil as influenced by temperature, moisture content and electrolyte concentration. Weed Science, v.26, n.3, p.303-308, 1978.

Dettenmaier, E.; Doucette, W.J. Mineralization and plant uptake of C-14 labeled nonylphenol, nonylphenol tetraethoxylate, and nonylphenol nonylethoxylate in biosolids/soil systems planted with crested wheatgrass. Environmental Toxicology and Chemistry, v.26, n.2, p.193-200, 2007.

Dettmer, K.; Aronov, P.A.; Hammock, B.D. Mass spectrometry-based metabolomics. Mass Spectrometry Reviews, v.26, n.5, p.51-78, 2007.

EPA - Environemental Protection Agency. Fate, transport and transformation test guidelines. EPA, 2008. Available from: <www.epa.gov/ oppts $>$. Accessed: 14 mar. 2017.

Etzerodt, T.; Mortensen, A.G.; Fomsgaard, I.S. Transformation kinetics of 6 methoxybenzoxazolin2-one in soil. Journal of Environmental Science Health, v.43, n.5, p.1-7, 2008.

Fenner, K.; Canonica, S.; Wackett, L.P.; Elsner, $M$. Evaluating pesticide degradation in the environment: blind spots and emerging opportunities. Sciencemag, 2013. Available from: <www.sciencemag.org>. Accessed: 14 mar. 2017.

Foght, J.; April, T.; Biggar, K.; Aisabie, J. Bioremediation of DDT-contaminated soils: a review. Bioremediation Journal, v.5, n.3, p.225-246, 2001.

Fomsgaard, I.S.; Kristensen, K. Influence of microbial activity, organic carbon content, soil texture and soil depth on mineralisation rates of low concentrations of C-14-mecoprop - development of a predictive model. Ecological Modelling, v.122, p.45-68, 1999.

Fushiwaki, Y.; Urano, K. Adsorption of pesticides and their biodegraded products on clay minerals and soils. Journal of Health Science, v.47, n.4, p.429-432, 2001.
Gali, R.K.; Cryer, S.A.; Poletika, N.N.; Dande, P.K. Modeling Pesticide Runoff from Small Watersheds Through Field-Scale Management Practices: Minnesota Watershed Case Study with Chlorpyrifos. Air, Soil and Water Research, v.9, n.3, p.113-122, 2016.

Gavrilescu, M. Fate of pesticides in the environment and its bioremediation. Engineering in Life Sciences, v.5, n.1, p.497-526, 2005.

Gorecki, T.; Namiesnik, J. Passive sampling. Trac-Trends in Analytical Chemistry, v.21, n.1, p.276-291, 2002.

Goss, D.W. Screening procedure for soils and pesticides for potential water quality impacts. Weed Technology, v.6, n.1, p.701-708, 1992.

Gustafson, D.I.; Holden, L.R. Nonlinear pesticide dissipation in soil: a new model based on spatial variability. Environmental Science \& Technology, v.24, n.7, p.1032-1038, 1990.

Helling, C.S.; Turner, B.C. Pesticide mobility: determination by soil thin-layer chromatography. Science, v.162, p.562-563, 1968.

Hussain, A.; Ghafoor, A.; Anwar-ul-Haq, M.; Nawaz, M. Application of the Langmuir and Freundlich Equations for P Adsorption Phenomenon in Saline-Sodic Soils. International Journal of Agriculture and Biology, v.5, n.3, p.349-356, 2003.

IUPAC - International union of pure and applied chemistry. Pesticide runoff: methods and interpretation of field studies. Pure and Applied Chemistry, v.67, n.12, p.2089-2108, 1995.

Jene, B.; Fent, G.; Kubiak, R. Transport of [14C] benazolin and bromide in large zero-tension outdoor lysimeters and the undisturbed field in a sandy soil. Pest Management Science, v.55, n.4, p.500-501, 1999.

Kan, A.T.; Fu, G.M.; Hunter, M.A.; Thompson, M.B. Sorption/desorption hystereses in organic pollutant and soil/sediment interactions. 
Environmental Science \& Technology, v.28, n.5, p.859-867, 1994.

Kasteel, R.; Putz, T.; Vereecken, H. An experimental and numerical study on flow and transport in a fi eld soil using zero-tension lysimeters and suction plates. European Journal of Soil Science, v.8, n.3, p.632-645, 2007.

Lam, P.K.S. Gray, J.S. The use of biomarkers in environmental monitoring programmes. Marine Pollution Bulletin, v.46, n.2, p.182-186, 2003.

Leistra, M.; Wolters, A.; van den Berg, F. Volatilisation and competing processes computed for a pesticide applied to plants in a wind tunnel system. Pest Management Science, v.64, n.6, p.669-675, 2008.

$\mathrm{Li}, \mathrm{R}$. Modeling of pesticide emissions from agricultural ecosystems. Journal of Geophysical Research, v.117, n.7, p.1-13, 2012.

Lindahl, A.M.L.; Söderström, M.; Jarvis, N. Influence of input uncertainty on prediction of within-field pesticide leaching risks. Journal of Contaminant Hydrology, v.98, n.2, p.106-114, 2008.

Linn, D.M.; Carski, T.H.; Brusseau, M.L.; Chang, F.H. (Eds.). Sorption and degradation of pesticides and organic chemicals in soil. Madison: Soil Science Society of America, 1993. 260p.

Logan, B.E. (Ed.). Environment transport processes. New York: John Wiley and Sons, 1999. 482p.

Lourencetti, C.; Marchi, M.R.R.; Ribeiro, M.L. Influence of sugar cane vinasse on the sorption and degradation of herbicides in soil under controlled conditions. Journal of Environmental Science and Health. Part. B, Pesticides, Food Contaminants, and Agricultural Wastes, v.47, n. 10, p.949-958, 2012.

Mahugija, J.A.M.; Henkelmann, B.; Schramm, K.W. Levels and patterns of organochlorine pesticides and their degradation products in rainwater in
Kibaha Coast Region, Tanzania. Chemosphere, v.118, p.12-19, 2015.

Majewski, M.S. Micrometeorological methods for measuring the post-application volatilization of pesticide. Water, Air, and Soil Pollution, v.115, n.1, p. 83-113, 1999.

Melo, C.A.D.; Dias, R.C.; Mendes, K.F.; Assis, A.C.L.P.; Reis, M.R. Herbicides carryover in systems cultivated with vegetable crops. Revista Brasileira de Herbicidas, v.15, n.1, p.67-78, 2016.

Moreira Junior, O.; Antuniassi, U.R. Construção e validação de um túnel de vento para ensaios de estimativa da deriva em pulverizações agrícolas.

Revista Energia na Agricultura, v.25, n.3, p.118-136, 2010.

Nichols, P.H. (Ed.). Organic contaminants in soils and ground-waters. In: Jones, K.C. Organic Contaminants in the Environment. Amsterdam: Elsevier, 1992. p. 87-129.

Nunes, A.L.; Vidal, R.A. Seleção de plantas quantificadoras de herbicidas residuais. Revista de Ecotoxicologia e Meio Ambiente, v.19, n.1, p. 19-28, 2009.

OECD - Organização para a Cooperação e Desenvolvimento Económico. Guideline for testing of chemicals: principles and strategies related to the testing of degradation of organic chemicals. OECD, 2005. Available from: $<$ http:// www.oecd.org/env/ehs/testing/34898616.pdf>. Accessed: 15 mar. 2017.

Pimentel, D. Effects of pesticides on the environment. In: 10th International Congress on Plant Protection, 10., 1983, Crydon. Proceedings... Birmingham: British Crop, 1983. p.685-691.

Ronco, A.E.; Marino, D.J.G.; Abelando, M.; Almada, P.; Apartin, C.D. Water quality of the main tributaries of the Paraná Basin: glyphosate and AMPA in surface water and bottom sediments. Environmental Monitoring and Assessment, v.188, n. 8, p.458, 2016. 
Rupak, P.; Sharma, R.; Kulshrestha, G.; Singh, S.B. Analysis of metsulfuron-methyl residues in wheat field soil: a comparison of HPLC and bioassay techniques. Pest Management Science, v.65, n.9, p.963-968, 2009.

Sakai, N.; Dayana, E.; Bakar, A.A.; Yoneda, M.; Sulaiman, N.M.N.; Mohd, M.A. Occurrence, distribution, and dechlorination of polychlorinated biphenyls and health risk assessment in Selangor River basin. Environmental Monitoring and Assessment, v.188, n.10, p.592, 2016.

Scheyer, A.; Morville, S.; Mirabel, Ph.; Millet, M. A multi residue method using ion trap gas chromatography-tandem mass spectrometry with or without derivatization with penta fluorobenzylbromide for the analysis of pesticides in the atmosphere. Analytical and Bioanalytical Chemistry, v.381, n.2, p.1226-1233, 2005.

Schreiber, F.; Avila, L.A.; Scherner, A.; Gehrke, V.R.; Agostinetto, D. Volatility of different formulations of clomazone herbicide. Planta Daninha, v.33, n.33, p.315-321, 2015.

Schreiber, F.; Avila, L.A.; Scherner, A.; Moura, D.S.; Helgueira, D.B. Plants sensitive to clomazone in vapor phase. Ciência Rural, v.43, n.43, p.18171823, 2013.

Schreiber, F.; Avila, L.A.; Scherner, A.; Moura, D.S.; Martini, A.T. Volatilidade de formulações de clomazone em condições de campo. Revista Brasileira de Herbicidas, v.15, n.3, p.271-280, 2016.

Schummer, C.; Mothiron, E.; Appenzeller, B.M.R.; Rizet, A.L.; Wennig, R.; Millet, M. Temporal variations of concentrations of currently used pesticides in the atmosphere of Strasbourg, France. Environmental Pollution, v.158, p.576-584, 2010.

Schummer, C.; Tuduri, L.; Briand, O.; Appenzeller, B.M.; Millet, M. Application of XAD-2 resinbased passive samplers and SPME-GC-MS/ MS analysis for the monitoring of spatial and temporal variations of atmospheric pesticides in
Luxembourg. Environmental Pollution, v.170, p.88-94, 2012.

Shigaky, F.; Dell, C.J. Comparison of low-cost methods for measuring ammonia volatilization. Agronomy Soils \& Environmental Quality, v.107, n.4, p.1392-1400, 2015.

Shukla, S.; Srivastava, S.; Hardin, J.D. Design, construction, and installation of large drainage lysimeters for water quantity and quality studies. Applied Engineering in Agriculture, v.22, n.1, p.529-540, 2006.

Singh, R.; Gerritse, R.G.; Aylmore, L.A.G. Adsorption desorption behaviour of selected pesticides in some Western Australian soils. Australian Journal of Soil Research, v.28, n.2, p.227-243, 1990.

Strachan, S.D.; Nanita, S.C.; Ruggiero, M.; Casini, M.S.; Heldreth, K.M.; Hageman, L.H.; et al. Correlation of chemical analysis of residual levels of aminocyclopyrachlor in soil to biological responses of alfalfa, cotton, soybean, and sunflower. Weed Technology, v.25, n.2, p.239-244, 2011.

Tiktak, A.; Berg, F.; Boesten, J.J.T.I.; Leistra, M.; Linden, A.M.A.; Kraalingen, D. (Eds.). Pesticide emission assessment at regional and local scales: user manual of Pearl version 1.1.1. Bilthoven: RIVM, 2000. Available from: <http://www.pearl. pesticidemodels.eu/pdf/pearlman.pdf $>$. Accessed: 14 mar. 2017.

Tiktak, A.; de Nie, D.S.; Garcet, J.D.P.; Jones, A.; Vanclooster, M. Assessment of the pesticide leaching risks at the Pan-European level: the Euro PEARL approach. Journal of Hydrology, v.289, n. 4, p.222-238, 2004.

Van den Berg, F.; Kubiak, R.; Benjey, W.G.; Majewski, M.S.; Yates, S.R.; Reeves, G.L.; et al. Emission of pesticides into the air. Water, Air, and Soil Pollution, v.115, n.1, p.195-218, 1999.

Waldman, M.; Shevah, Y. Biodegradation and leaching of pollutants: monitoring aspects. Pure Applied Chemosphere, v.65, n.7, p.1595-1603, 1993. 
Wania, F.; Shen, L.; Lei, Y.D.; Teixeira, C.; Muir, D.C. Development and calibration of a resinbased passive sampling system for monitoring persistent organic pollutants in the atmosphere. Environmental Science \& Technology, v.37, n.3, p.1352-1359, 2003.

Wauchope, R.D.; Burgoa, B. (Eds.). Agrochemical chemical environmental fate studies: state of the art. Chelsea: Lewis Publishers, 1995. p.273-285.

Wauchope, R.D.; Yeh, S.; Linders, J.B.; Kloskowski, R.; Tanaka, K.; Rubin, B.; et al. Pesticide soil sorption parameters: theory, measurement, uses, limitations and reliability. Pest Management Science, v.58, n.5, p.419-445, 2002.
Westra, E.P.; Shaner, D.L.; Westra, P.H.; Chapman, P.L. Dissipation and leaching of pyroxasulfone and $S$-metolachlor. Weed Technology, v.28, n.1, p.72-81, 2014.

Whitford, F.; Wolt, J.; Nelson, H.; Barrett, M.; Brichford, S.; Turco, R. Pesticides and water quality principles, policies and programs. West Lafayette: Purdue University, 1995. Available from: <www.extension.purdue. edu/extmedia/ppp/ppp-35.pdf $>$. Accessed: 15 mar. 2017.

Zhang, J.; Lan, W.; Qiao, C.; Jiang, H.; Mulchandani, A.; Chen, W. Bioremediation of organophosphorus pesticides by surface-expressedcarboxylesterase from mosquito on Escherichia coli. Biotechnology Progress, v.20, p.1567-1571, 2004. 